\title{
Kearifan Lokal Malangan dalam Kumpulan Cerpen Aloer-Aloer Merah Karya Ardi Wina Saputra
}

\author{
Mega Fransiska Ariani dan Eggy Fajar Andalas \\ Universitas Muhammadiyah Malang \\ mega.ariani07@gmail.com \\ eggy@umm.ac.id
}

\begin{abstract}
Abstrak
Penelitian ini bertujuan untuk mengungkapkan kearifan lokal Malangan yang terdapat pada kumpulan cerpen Aloer-Aloer Merah karya Ardi Wina Saputra. Untuk menjawab permasalahan tersebut digunakan konsep kearifan lokal melalui pendekatan antropologi sastra. Penelitian ini merupakan jenis penelitian kualitatif dengan bentuk deskriptif. Teknik pengumpulan data dilakukan dengan cara membaca keseluruhan kumpulan cerpen. Analisis data dilakukan dengan cara sebagai berikut: 1) membaca keseluruhan kumpulan cerpen, 2) mengidentifikasi data, 3) mengklasifikasi data, 4) menganalisis dalam bentuk deskriptif dengan menggunakan penafsiran peneliti, 5) menyimpulkan hasil temuan, 6) menulis laporan hasil penelitian. Hasil penelitian menunjukkan bahwa dalam Ardi Wina Saputra menghadirkan cerita tentang kearifan lokal dalam aspek bahasa, aspek aktivitas atau mata pencaharian, dan aspek religi.
\end{abstract}

Kata Kunci: nilai-nilai; kearifan lokal; antropologi; bahasa; religi.

\begin{abstract}
This study aims to reveal the local wisdom of Malangan in the collection of AloerAloer Merah short stories by Ardi Wina Saputra. To answer these problems, used the concept of local wisdom with a literary anthropological approach. This research is a type of qualitative research with a descriptive form. Data collection techniques are done by reading the entire collection of short stories. Data analysis was carried out in the following way: 1) reading the entire collection of short stories, 2) identify data, 3) classifying data, 4) analyze in descriptive form by using the researcher's interpretation, 5) conclude the findings, 6) write a report on the results of the study. The results of the study show that in ArdiWinaSaputra presents stories about local wisdom in aspects of language, aspects of activity or livelihood, and religious aspects.
\end{abstract}

Keywords: values; local wisdom; literary anthropological; language; religion 


\section{PENDAHULUAN}

Budaya lahir dari keleluhuran nilai, kemuliaan sikap, dan keagungan tradisi terhadap sikap masyarakat yang telah berjalan secara berkelanjutan. Budaya lahir melalui proses dari adanya interaksi yang terkadang megalami akulturasi dari keyakinan religi, sosial dan tradisi masyarakat (Mujahidin, 2016:1). Manusia yang beradap akan membangun budaya melalui dasar dari nilainilai kearifan lokal (Mujahidin, 2016:2). Vicentius (2009:87) mengatakan bahwa nilai merupakan suatu penghargaan yang diberikan kepada sesuatu yang baik dan benar. Dari pengertian tersebut dapat diartikan bahwa nilai adalah penghargaan yang diberikan kepada benda agar benda tersebut dapat bermanfaat untuk memenuhi kebutuhan masyarakat (Yunus, 2014:17). Nilai merupakan sebuah hal yang berharga dalam kehidupan. Nilai dianggap sebagai patokan kehidupan yang member makna dalam hidup (Aslan, 2017:13). William (dalam Aslan, 2017:13) mengatakan bahwa nilai merupakan "...what is desirable, good or bad beautiful or ugly". Light, Keller \& Colhoun mengemukakan bahwa nilai “... is general idea that people share about what is good or bad, desirable or undesirable. Value transcend any one particular situation... Value people bold tend to color their overall way of life". Djahiri (dalamYunus, 2014:17) mengatakan bahwa nilai memiliki pengaruh yang sangat penting karena nilai memiliki pengaruh pegangan emosional seseorang (Value are powerful emotional commitment). Nilai dijadikan alat kontrol yang dianggap sebagai nilai agama dan menjadi pedoman bagi kehidupan. Dari pemaparan tersebut nilai merupakan patokan hidup masyarakat yang diwariskan nenek moyang sebagai kearifan lokal. Kearifan telah lama mengalami perubahan dari generasi kegenerasi. Secara etimologi kearifan lokal berarti kemampuan seseorang dalam menggunakan akal pikirannya untuk menanggapi suatu tindakan, kejadian, atau situasi. Lokal berarti suatu kejadian yang terjadi pada suatu daerah. Kearifan lokal adalah pola pikir positif yang berhubungan dengan alam, lingkungan yang bersumber pada adat istiadat, nilai agama, petuah-petuah nenek moyang yang terbentuk dalam suatu daerah sebagai tradisi.

Banyak karya sastra yang mengambil nilai-nilai kearifan lokal. Salah satu karya sastra yang isinya banyak memaparkan kearifan lokal adalah Kumpulan Cerpen Aloer-Aloer Merah. Kearifan lokal yang banyak diceritakan adalah kearifan lokal Malang. Kumpulan cerpen Aloer-Aloer Merah berisikan 10 cerpen yang 8 diantaranya menggunakan seting kota Malang dan 2 diantaranya di Surabaya. Dari 8 judul cerpen yang menggunakan seting kota Malang adalah Aloer-Aloer Merah. Dalam cerpen tersebut diceritakan tentang dendam seorang pribumi pada penjajah. Cerpen tersebut juga menceritakan aktivitas sehari-hari masyarakat Malang yang digambarkan sebagai seorang pribumi yang bermata pencaharian sebagai petani Aloer-Aloer. Kumpulan cerpen tersebut banyak disisipkan nilai-nilai kearifan lokal asli Malang.

Malang merupakan salah satu daerah yang memiliki banyak kearifan lokal. Kearifan lokal yang menojol di Malang adalah bahasa Jawa Walikan, bahasa ini merupakan kearifan lokal Malang yang sudah tumbuh dan berkembang sejak dahulu. Ada juga kebiasaan 
masyarakat yang termasuk dalam kearifan lokal yaitu melakukan ritual di Gunung Kawi. Oleh karenanya penelitian ini berfokus pada kearifan lokal Malangan yang terdapat pada kumpulan cerpen Aloer-Aloer Merah Karya Ardi Wina Saputra.

Tujuan penelitian ini adalah membedah kearifan lokal Malangan yang terdapat pada Kumpulan CerpenAloer-Aloer Merah karya Ardi Wina Saputra. Dalam kumpulan cerpen tersebut tidak hanya menyinggung tentang tempat kejadian cerita yang berseting di Malang, namun dalam segi pola pikir, bahasa dan religi banyak diceritakan dari masyarakat kota Malang. Sejauh dari penelusuran peneliti kumpulan cerpen ini belum pernah dilakukan. Penelitian ini penting dilakukan karean belum pernah ada penelitian pada kumpulan cerpen tersebut. Oleh karena itu penelitian ini merupakan penelitian pertama yang dilakukan dalam Kumpulan Cerpen Aloer-Aloer Merah Karya Ardi Wina Sapura.

Untuk menjawab tujuan dari penelitian ini peneliti menggunakan konsep kearifan lokal. Ratna (2011:343) mengatakan bahwa semua kebudayaan seperti adat istiadat dan kearifan lokal merupakan implikasi dari masa lampau. Kearifan lokal yang terdapat pada kumpulan cerpen ini menggunakan pendekatan antropologi sastra. Pendekatan antropologi sastra merupakan pendekatan yang mengkaji tentang analisi dan pemahaman terhadap karya sastra yang berkaitan dengan budaya (Ratna, 2011:342). Untuk menyelesaikan permasalahan tersebut menggunakan peneliti berfokus pada nilai-nilai kearifan lokal. Nilai yang merupakan hal terpenting dalam kehidupan. Nilai yang dianggap sebagai patokan kehiduapan dalam bermasyarakat untuk menentukan suatu tindakan. Nilai memiliki banyak makna didalamnya. Kearifan lokal adalah sebuah budaya yang tidak terlepas dari suatu kelompok masyarakat. Kearifan lokal yang tubuh dari pemikiran nenek moyang yang telah diwariskan untuk generasigenerasinya. Kearifan lokal juga merupakan penanda dari suatu kelompok masyarakat.

\section{METODE}

Penelitian ini merupakan jenis penelitian kualitatif. Jenis penelitian kualitatif adalah jenis penelitian yang secara menyeluruh menggunakan cara-cara penafsiran dengan mengkaji dalam bentuk deskriptif (Ratna, 2011:46). Pendekatan yang digunakan adalah pendekatan antropologi sastra, khususnya pada nilai-nilai kearifan lokal.

Sumber dari penelitian ini berupa Kumpulan Cerpen Aloer-Aloer Merah karya Ardi Wina Saputra. Data penelitian diambil dari membaca seluruh cerpen. Data penelitian ini berupan teks yang data tersebut merupakan cetakan pertama dengan 10 judul, dari 10 judul tersebut peneliti berfokus pada 8 judul yang menggunakan seting kota Malang, sedangkan 2 diantaranya menggunakan seting kota Surabaya. Sumber data yang telah diterbitkan oleh Pelangi Sastra pada tahun 2017 dengan jumlah halaman 126. Sumber data memperlihatkan permasalah pada kumpulan cerpen tersebut. Permasalahan yang diperlihatkan berupa kearifan lokal yang menonjol yang diceritakan pada kumpulan cerpen tersebut.

Teknik pengumpulan data yang dilakukan diperoleh dari beberapa langkah yaitu: Pertama, membaca keseluruhan Kumpulan Cerpen Aloer-Aloer Merah karya Ardi Wina 
Saputra. Kedua, memahami setiap isi cerita dari kumpulan cerpen tersebut. Ketiga, mengidentifikasi permasalah yang menojol dalam kumpulan cerpen tersebut. Keempat, melakukan studi kepustakaan yang berkaitan dengan representasi nilai-nilai kearifan lokal. Kelima, menandai dan mencatat objek penelitian yang terdapat dalam isi cerita. Keenam, mengklasifikasi data yang berhubungan dengan representasi nilai-nilai kearifan lokal.

Penelitian ini menggunakan instrumen panduan data. Instrumen panduan data yang berisi rumusan masalah, sub-masalah, data dan interpretasi. Instrumen panduan data berfungsi sebagai alat untuk mempermudah peneliti dalam mencari data dan mengelompokkan data.

Teknik Analisis data yang digunakan dalam kumpulan cerpen Aloer-Aloer Merah meliputi, Pertama mengidentifikasi data yang diperoleh dari kumpulan cerpen Aloer-Aloer Merah karya Ardi Wina Saputra. Kedua mangkasifikasi data yang sesuai dengan kearifan lokal pada Kota Malang. Ketiga menganalisis dalam bentuk deskripsi menggunakan penafsiran peneliti. data. Keempat menyimpulkan hasil temuan. Kelima menulis laporan hasil penelitian..

\section{HASIL DAN PEMBAHASAN}

Dalam kumpulan cerpen ini banyak ditemukan bentuk-bentuk kearifan lokal Malangan. Bentuk-bentuk kearifan lokal tersebut dapat terlihat pada aspek 1) bahasa, 2) aktivitas dan mata pencaharian, 3) religi. Berikut pembahasan mengenai hal tersebut.

\section{Nilai Kearifan Lokal Malangan dalam aspek Bahasa}

Bahasa merupakan sarana komunikasi manusia. Di Malang terdapat kearifan-kearifan lokal yang berupa bahasa yang digunakan sebagai alat komunikasi masyarakat. Rosyid (2014:179) mengatakan bahwa bahasa sebagai alat komunikasi yang memiliki fungsi kognitif yaitu dalam penggunaanya bahasa sebagai alat dalam menyampaikan isi pikiran. Masyarakat mengatakan bahasa bukan sekedar alat komunikasi tapi juga sebagai sarana pemertahanan budaya. Artinya, budaya mengendap dalam bahasa-bahasa lokal Malangan. Dalam kumpulan cerpen ini kearifan-kearifan lokal yang terdapat dalam bahasa-bahasa sebagai berikut.

"Mas Darto, Matur Nuwun semenjak mas bekerja di sini, aloer-aloer tampakl segar dan tumbuh subur". (paragraph 1 hal.2)

Data tersebut berasal dari salah satu judul yang terdapat pada kumpulan cerpen yaitu Aloer-Aloer Merah. Tokoh Ranggah Guntur mengucapkan terimakasih dengan menggunkan bahasa lokal kepada tokoh Darto. Ucapan terimasih yang disampaikan tokoh ranggah guntur tersebut sebagai rasa senang terhadap hasil kerja yang telah dilakukan oleh Darto.

Pada peristiwa tersebut kata matur nuwun yang diucapkan ranggah guntur tidak hanya memiliki makna ucapan rasa terimakasih atas bantuan yang diterimanya. Dalam konteks masyarakat Malang terdapat makna budaya dibalik kata tersebut. Wijana (dalam Khoerot:28-29) mengatakan bahwa dalam 
menjaga dan mempertahankan hubungan baik dengan seseorang, maka kita harus pandai menempatkan diri baik dalam perilaku maupun tutur kata. Selain memiliki makna budaya kata tersebut juga memiliki makna dalam konteks sosial. Dalam kontek sosial kata tersebut memiliki makna tindakan sopan santun kepada seseorang. Dalam aspek bahasa keratifan lokal malangan juga terdapat kata ae yang terdapat pada kutipan berikut.

\section{“hei. Ngelamun ae!"tiba-tiba Ranggah Guntur menepuk pundak ku. "ayo naik keatas kita pulang," ujarnya. (paragraph 2 hal.2)}

Data tersebut diperoleh dari cerpen yang berjudul Aloer-aloer merah. Kutipan tersebut menceritakan bahwa tokoh Ranggah yang sedang menegur Darto. Dalam kutipan tersebut diceritakan tokoh Darto yang sedang melamun disawah aloer-aloer. Ranggah menegur Darto sembari mengajak untuk balik pulang ke rumah karena waktu sudah menjelang sore.

Pada peristiwa tersebut terdapat kata ae yang diucapkan oleh Ranggah Guntur. Kata ae merupakan salah satu ciri khas bahasa yang terdapat pada kota Malang. Kata ae dalam bahasa Indonesia yaitu saja. Dalam bahasa jawa kata ae merupakan sebuah penegasan salam satu aktivitas atau tindakan. Kata ae merupakan teguran masyarakat Malang pada seseorang yang sedang melakukan aktivitas atau tindakan yang dilakukan terus-menerus tanpa berhenti. Kearifan lokal Malangan yang tergambar pada cerita juga terdapat pada kata le yang terdapat pada kutipan berikut.
"Le, semenjak orang tuamu tiada, kau sebenarnya sudah ku anggap sebagai anakku sendidiri". Kata Ranggah. "Le, coba pikirkan baik-baik tentang keamanan di negeri ini yang tidak menentu apalagi semenjak Tuan Boestra menjabat sebagai Burgemeester, kalau tidak menurut matilah kita. Itu sebabnya, aku memberimu dua pilihan!" tegasnya. (paragraph 2 hal.3-4)

Data tersebut berasal dari salah satu judul yang terdapat pada kumpulan cerpen yaitu Aloer-Aloer Merah. Tokoh Ranggah Guntur yang memangil tokoh Darto yang sudah dianggap sebagai anaknya sendiri. Dalam kutipan tersebut tokoh Ranggah Guntur berusaha membujuk Darto agar tidak melakukan rencananya. Panggilan yang diucapkan oleh Ranggah Guntur tersebut sebagai orang tua yang memanggil anak lakilakinya.

Pada dialog tersebut kata Le yang diucapkan Ranggah dalam kontek budaya memiliki makna budaya panggilan orang yang lebih tua kepada anak laki-laki. Poedjosoedarmo (dalam Kawasari, 2017:3233) penyebab pemilihan tutur kata terdapat pada dua faktor, yaitu tingkat formalitas penutur dan mitra tutur dan status sosial mitra tutur. Dalam segi faktor sosial, terbagi menjadi empat faktor tuturan yang menyebabkan seseorang memilih tingakat tutur apa yang harus di digunkan. Empat faktor tersebut yaitu tingkat pangkat, kebangsawanan, ekonomi dan pendidikan formal. Dari segi formalitas dibagi lagi dalam tingkat keakrapan hubugan antar mitra tutur, tingkat keangkeran mitra tutur, dan usia mitra tutur (Kawasari, 2017:32-33). Tidak hanya konteks budaya saja, namun terdapat 
makna konotasi dalam kontek sosial yang artinya mengarah pada tindakan etika agar seorang anak atau orang yang lebih muda ingat bahwa ia sedang berbicara pada orang yang lebih tua darinya. Kearifan lokal yang terdapat dalam cerita tidak hanya kata matur nuwun dan le saja, namun juga terdapat kata sampun yang terdapat pada kutipan berikut.

"saya sampun menentukan dan membulatkan tekat saya!' (paragraph 2 hal.4)

Data tersebut diperoleh dari dialog antar tokoh yang terdapat pada judul cerpen AloerAloer Merah. Dalam data tersebut tokoh Darto menyampaikan kepada Ranggah Guntur bahwa dia sudah memilki tekat yang kuat. Dialog tersebut Darto berusaha untuk meyakinkan Ranggah Guntur bahwa rencana yang telah dia buat akan tetap dilakukan dan meyakinkan Ranggah Guntur bahwa ia akan berhasil dengan rencananya.

Kata Sampun dalam bahasa Indonesia berarti sudah. Namun dalam dialog tersebut dijelaskan sebagai penegasan tentang apa yang dilakukan oleh tokoh. Kata sampun dalam bahasa jawa merupakan tutur krama. Wedhawati (dalam Setiyanto, 2010:1). Salah satu aspek pembinaan bahasa Jawa pemakaian tutur krama merupakan ragam baku. Tutur krama adalah variasi bahasa dengan femdan kosakata krama, yang digunakan untuk berkomunikasi dengan seseorang yang masih belum akrab dan status sosial lebih tinggi. Poedjosoedarmono (dalam Setiyanto, 2010:1) mengatakan bahwa tingkat tutur krama merupakan tingkat dalam menyampaikan sikap sopan yang tinggi. Kata sampun memiliki makna dalam aspek sosial yaitu sebagai tindakan sopan santun kepada yang lebih tua. Dalam bahasa Jawa kata tersebut digunakan hanya kepada anak muda kepada orang yang lebih tua.

"sengaja memang $k u$ sembunyikan kedokku agar rekan-rekan seperjuangan tidak ada rekan-rekan seperjuangan tidak ada yang menganggapku sebagai londo ireng. "(paragraph 2 hal.4)

Data tersebut diperoleh dari salah satu cerpen dari kumpulan Cerpen Aloer-Aloer Merah yang berjudul Senja Terakhir. Dalam data tersebut tokoh Sukarso menjelaskan bahwa ia sebenarnya adalah salah satu pejuang Indonesia yang menyusup pada salah satu sekolah milik belanda. Tokoh tersebut menyamar sebagai tukang sapu sekolah demi mengabdikan dirinya untuk nusa dan bangsa. Ia menyembunyikan identitas aslinya agar pejuang-pejuang lain tidak mengenalinya dan supaya ia tidak disebut sebagai penghianat atau Londo ireng.

Londo Ireng merupakan sebutan dalam bahasa jawa pada masa penjajahan. Londo ireng pada masa kini memiliki arti bahawa warga negara Indonesia yang berperilaku dan berpakaian seperti layaknya seorang turis. Kata londo ireng merupakan sebutan dari pribumi-pribumi untuk sesama pribumi yang bekerja sama dengan belanda untuk melakukan pengkhianatan kepada negaranya sendiri (Manijo, 2016:52).

Nilai kearifan lokal Malangan pada Aspek Aktivitas dan Mata Pencaharian 
Aktivitas dan mata pencaharian merupakan sarana komunikasi dalam aspek sosial. Aktivitas dan mata penaharian masyarakat merupakan salah satu nilai dari kearifan lokal dalam suatu daerah. Di Malang terdapat kearifan lokal yang berupa aktivitas dan Mata pencaharian yang menjadi ciri khas sebagai budaya. Dalam pembahasan ini peneliti menerapkan kajian arkepital, sebab objek dalam pembahasan ini aktivitas kehidupan masyarakat. Sudjijono (2002:4) dalam Setyorini \& Riskiana, 2017:96) mengatakan bahwa kajian arkepital dapat digunakan untuk mengenali warisan klasik, nilai-nilai primodial yang khas, yang dijadikan sebagai pedoman dalam aktivitas kehidupan. Artinya, aktivitas dan mata pencaharian merupakan apa saja yang dilakukan oleh seseorang atau kelompok orang yang dilakukan sebagai sesuatu yang berulang dan berkelanjutan sebagai budaya. Budaya tidak hanya mengendap pada bahasa namun juga mengendap pada aktivitas dan mata pencaharian lokal Malang. Dalam Kumpulan cerpen ini kearifan-kearifan lokal yang terdapat dalam aktivitas dan mata pencaharian sebagai berikut.

\section{"tepat disampingnya, tumbuh berjajar berbaris rapi selada-selada hijau siap panen. Penduduk sekitar menyebut itu dengan aloer-aloer." (paragraph 1 hal.1) \\ "Mas Darto, Matur Nuwun semenjak mas bekerja di sini, aloer-aloer tampak segar dan tumbuh subur". (paragraph 1 hal.2)}

Data tersebut diperoleh dari cerpen yang berjudul Aloer-Aloer Merah. Dalam kutipan tersebut diceritakan bahwa tokoh Darto yang sedang duduk di pinggiran subermata air yang telah ditanami selada atau aloer-aloer. Kutipan tersebut menceritakan aktifvitas dan mata pencaharian tokoh Darto sebagai petani aloer-aloer.

Petani tidak hanya sebagai aktivitas dan mata pencaharian sehari-hari untuk melangsungkan hidup. Namun petani merupakan salah salah satu kearifan lokal yang menonjol dalam suatu daerah sebagai ciri khas budaya. Di Malang mayoritas masyarakatnya bermata pencaharian sebagai petani. Kearifan lokal yang disebut sebagai local wisdom memiliki makna bahwa struktur sosial masyarakat mengandung sifat arif yang ditujukan untuk kepentingan bersama. Masyarakat mengatakan bahwa petani merupakan kearifan lokal mutlak yang mengandung nilai-nilai sosial yang digunakan sebagai pedoman perilaku untuk menjaga kelestarian ekosistem sumber daya (Santoso, 2006:14). Dalam aspek aktivitas dan mata pencaharian keratifan lokal Malangan juga tergambar pada kutipan berikut.

"profesi sebagai tukang sapu di sisni sudah ku mulai sejak dua tahun terakhir. Pekerjaan ini sengaja kutekuni sebgai wujud pengabdian ku kepada nusa dan bangsa". (paragraph 3 hal.27)

Data tersebut diperoleh dari salah satu judul cerpen yang terdapat di dalam kumpulan Cerpen Aloer-Aloer Merah.Kutipan tersebut menceritakan bahwa tokoh Sukarso bekerja sebagai tukang sapu. Selama 2 tahun ia telah bekerja sebagai tukang sapu di sekolah milik belanda. Ia menekuni perkerjaannya sematamata hanya untuk mengabdikan dirinya untuk nusa dan bangasanya. Sukarso menekuni 
perkerjaanya supaya ia dapat mengorek informasi dari pihak Belanda.

Tukang sapu sekolah tidak hanya sebuah pekerjaan untuk melangsungkan hidup. Tukang sampu merupakan kearifan lokal Malang pada masa penjajahan. Profesi memiliki makna sebagai pengabdian terhadap bangsa.

"azan magrib dari masjid alun-alun kota memenuhi seisi gendang telingaku. Hampir seтиa orang mengentikan rutinitasnya. Ada yang sembahyang ada yang duduk beristirahat". (bab.7 paragraph 1 hal. 71)

Data tersebut diperoleh dari judul cerpen Lelaki Yang Berdiri Menatap Bianglala. Kutipan tersebut menceritakan suasana di alun-alun kota pada saat azan magrib berkumandang. Ketika azan magrib semua orang menghentikan segala aktivitasnya ada yang melakukan solat dan ada yang istirahat.

Menghentikan aktivitas ketika azan magrib menurut orang jawa adalah sebuah keharusan. Dalam hal tersebut khususnya masyarat Malang itu merupakan kearifan lokal yang berupa pantang larang. Menurut Hasim (2010:6) pantang larang merupakan sesuatu yang dilarang jika ada yang melanggarnya maka akan mendapat keburukan bagi si pelaku. Menurut Tenas (dalam Hasim, 2010:3) pantang hakekatnya ialah segala sesuatu yang ditabukan, dilarang, dibenci, dijauhi oleh sekelompok orang, karena apa bila dilanggar akan mengakibatkan musibah bagi pelaku dan juga menjadi malapetaka bagi masyarakat. Ketika azan Magrib masyarat Jawa mempercayai bahwa pada masa tersebut hantu berkeliaran. Namun dalam kontek sosial mengandung makan ketika azan magrib itu merupakan perpindahan dari siang ke malam dan waktu untuk masyarakat melakuakan ibadah solat magrib.

\section{Nilai Kearifan Lokal Malangan pada Aspek Religi}

Kepercayaan dalam kehidupan sudah menjadi daur hidup,maka religiuitas sangat sulit terganti. Di Malang terdapat kearifan lokal yang berupa kepercayaan yang dijadikan sebagai pondasi dalam kehidupan. Agama dan masyarakat merupakan hal yang tidak dapat dipisahkan. Munurut Rosyida (hal.3) agama dan masyarakat merupakan satu kesatuan yang tidak dapat dipisahkan dalam kehidupan. Kepercayaan merupakan sesuatu yang unik dan perlu untuk di perjalas, khususnya dalam transformasi religius yang tidak pernah ditemukan fakta intimidasi dan kekerasan yang masif pada mubalig Muslim terhadap komunitas pribumi (Rosyida, hal.1). Masyarakat mengatakan sistem kepercayaan bukan sekedar warisan budaya yang melekat, namun kepercayaan merupakan salah satu alat yang digunakan masyarakat dalam berkomunikasi dengan Tuhan mereka. Artinya sebuah kepercayaan yang telah mengendap merupakan kearifan lokal yang dapat dijadikan sebagai pedoman bagi generasi dalam melestarikan warisan nenek moyang. Dalam mumpulan cerpen ini kearifan lokal dalam aspek religi sebagai berikut.

"Sebelum Ranggah Guntrs tertidur, aku bersimpuh dihadapanya." (paragraf 2 hal. 4) 
Dalam kutipan tersebut diceritakan bahwa tokoh Darto yang sedang bersimpuh pada Ranggah Guntur. Darto mersimbuh pada Ranggah Guntur memiliki tujuan untuk meminta izin agar apa yang telah ia rencanakan tetap berjalan atas persetujuan Ranggah Guntur. Tidak hanya sekedar bersimpuh saja namun Darto memohon restu kepada Ranggah Guntur agar apa yang telah direncanakan dapat berjalan dengan lancar tanpa ada kendala. Tokoh Darto sudah menganggap Ranggah Guntur adalah orang tuanya sendiri jadi ia meminta restu kepada Ranggah Guntur.

Bersimpuh atau sungkem kepada oarang tua merupakan salah satu kearifan lokal yang terdapat di Malang. Menurut Irmawati (2013:319) Sungkem merupakan tanda untuk meminta restu. Makna simbolik dari hal tersebut ialah tanda bakti seoarang anak kepada orang tuanya yang telah membesarkanya. Etika Jawa seorang anak sangat memberikan penghormatan kepada yang lebih tua, dari segi tutur kata maupun tingkah laku. Jongkok merupak tanda dari orang yang muda sebagai rasa hormat dan tunduk kepada yang lebih tua. Doa restu selalu diharapkan oleh seorang anak dari kedua orang tuanya, agar apa yang dilakukan dapat pertolongan dari Tuhan dan mendapat keberkahan. Dalam aspek religi keratifan lokal Malangan juga tergambar dari kepercayaan Masyarakat Malang.

"itu karena kami masih percaya bahwa kesuburan tanah di tempat kami dijaga oleh roh nenek moyang. Namun semua terserah Tuan, jika Tuan ingin penelitian ini sia-sia maka bawalah tas
Tuan yang beraroma serbuk mesiu itu ke kebun," ujarku. (paragraph 4 hal.7)

Data tersebut diperoleh dari percakapan antar tokoh. Kutipan tersebut diambil pada salah satu judul cerpen yaitu Aloer-Aloer Merah. Kutipan tersebut menceritakan tohoh Darto yang membujuk orang Belanda untuk menaruh tasnya yang berisi senjata. Dalam kutipan tersebut tokoh Darto mengungkapkan bahwa keseburan tanah dijaga oleh roh nenek moyang. Dalam melakukan segala sesuatu maka harus menghormati roh nenek moyang agar penelitian yang dilakukan oleh orang Belanda.

Mempercayai ruh nenek moyang merupan salah satu tradisi yang masih kental di kota Malang. Salah satunya adalah ketika melakukan pekerjaan yang berhubungan tanaman pangan. Masyarakat masih mempercayai adanya penunggu yang menjaga kebun agar tetap subur. Dila \& Sudrajat (2017:5) mengatakan bahwa Salah satunya adalah kepercayaan terhadap Dewi Sri. Kepercayaan terdahulu dengan adanya Dewi sri sebagai Dewi Padi, Dewi Kemakmuran, dan Dewi dalam aspek pertanian. Dewi Sri diketahui merupaka seorang Dewi yang dibunuh dan kemudian jasadnya dibuang ke bumi. Ketika jasadnya dimakamkan tumbuh banyak tumbuhan yang sangat bermanfaat bagi manusia salah satunya adalah padi yang menjadi makanan pokok masyarakat Indonesia. Dari cerita tersebut masyarakat percaya bahwa ruh Dewi Sri adalah penjaga tanaman pertanian di lahan petani(Dila \&Sidjarat, 2017:5). Makna dari mempercayai hal tersebut dapat memberikan kemakmuran bagi masyarakat dan agar terhindar dari 
bencana alam dan hama pada tanaman. Selain kepercayaan terhadap ruh nenek moyang dalam cerpen tersebut diceritakan tentang agama yang dipeluk oleh masyarakat Malang.

"baik Jer, akan aku jelaskan, Aku tadi membaca kitab ku, namanya Al-Quran yang berarti bacaan. Tuhan pernah memerintahkan Iqro' pada nabi Muhammad, oleh karena itu ketika membaca Al-Quran aku harus membacanya dengan sungguh!” (bab 3 paragraph 1 hal. 30)

Data tersebut diperoleh dari salah satu cerpen yang berjudul Senja Terakhir yang terdapat pada kumpulan cerpen Aloer-Aloer Merah. Kutipan tersebut diperoleh dari percakapan antar tokoh. Dalam kutipan tersebut tokoh Sukarso menjelaskan kepada Jeral tentang bagaimana ia beribadah. Sukaro menjawab pertanyaan jeral tentang apa yang telah dibacanya. Sukaro menjelaskan kepada jeral bahwa yang ia baca adalah kitab dalam agamanya yaitu kitab Al-Quran. Sukarso menjelaskan bahwa kitab yang ia baca adalah perintah dari Tuhanya. Dari kutipan tersebut dapat diktikan bahwa agama yang dianut oleh Sukarso adalah Islam.

Al-Quran merupakan kitab suci agama Islam. Al-Quran adalah kalamullah, firman Allah SWT yang telah diturunkan kepada Nabi Muhammad selama 23 tahun. Al-Quran merupakan kitab suci umat islam yang dijadikan sumber petujuk dalam beragama dan pembimbing dalam menjalani kehidupan didunia dan akhirat (Gazali, 2010:2). Oleh karena itu, seuatu kewajiban bagi umat muslim untuk selalu membaca Al-Quran. Masyarakat muslim mengatakan jika ingin berinteraksi dengan Allah maka salah satu caranya adalah dengan membaca Al-Quran. Selain membaca masyarakat muslim diharapkan dapat mendalami makna yang terkandung dan mengamalkan semua yang telah diajarkan didalam Al-Quran kepada umat muslim lain. Dalam kumpulan cerpen Aloer-Aloer Merah kearifan lokal Malang juga ditunjukkan pada ritual-ritual yang dilakukan oleh masyarakat. Seperti yang terdapat pada kutipan berikut.

“Tahukah kau peristiwa
pemberontakan di stasiun kota setahun
silam, saat itu ratusan mortir dilempar
oleh anak buahmu secara
serampangan? Anak dan istrikupun
terkena getahnya sehingga aku hidup
menduda. Saat itu aku menjadi gila dan
berlari tak tahu arah hingga aku tiba di
bawah kaki Gunung Kawi. Di sana aku
bertemu seekor kuda putih dan bertapa
di gua yang disinggahinya. Raga ku dan
kuda itu menyatu, aku kini memiliki
kekebalan. Kau pasti tak menyangkan
semua ini terjadi kan Tuan Van
Marwijk? Di negerimu, hukum fisika
dan ilmu terbaik sekali pun bahkan tak
mampu membuktikan kejadian ini! Hai,
Dirkje Van Marwijk, ingat kau dimana?
Kau berada ditanah ku!” (bab.10
paragraf 2 hal. 117)

Data tersebut diperoleh dari cerpan yang berjudul Rawis yang terdapat pada kumpulan cerpen Aloer-Aloer Merah. Rawis dulunya adalah manusia biasa, ia sempt gila karena istri dan anaknya menjadi korban kekejaman orang Belanda. Hingga saatnya ia tiba di kaki Gunung Kawi dan bertapa di sebuah Gua bersama dengan kuda putih. Ketika bertapa tubuhnya menyatu dengan kuda tersebut sehingga ia mendapat kekebalan. Kekebalan yang ia miliki digunakan untuk balas dendam 
kepada pemimpin Belanda yaitu Dirkjen Van Marwijk.

Gunung Kawi terkenal dengan mistiknya, Gunung Kawi merupakan tempat ritual yang telah menjadi tujuan para pezirah terutama bagi masyarakat etnis Cina dan etnis lainya. Gunung Kawi terkenal dengan hal-hal yang berbau gaib. Banyak masyarakat yang datang kesana tidak hanya berziarah namun banyak pula masyarakat yang datang untuk mencari pesugihan. Gunung Kawi dalam masyarakat yang datang dengan tujuan baik dan ada juga yang memilki tujuan yang buruk. Biasanya masyarakat datang denga tujuan baik hanya melakukan ziarah pada makam yang terdapat di gunung Kawi. Namun, ada juga masyarakat yang datang dengan tujuan buruk serti menyembah atau meminta pesugihan sengan melakukan pertapaan atau ritul-ritual yang dapat membuat masyarakat bersekutu dengan setan.

\section{KESIMPULAN}

Kumpulan Cerpen Aloer-Aloer Merah berisikan tentang nilai-nilai kearifan lokal Malang. Hal itu dapat dilihat dari seting cerita yang digambarkan pada cerpen tesebut. Bentuk kearifan lokal yang tergambar pada kumpulan cerpen tersebut berupa aspek bahasa, aspek aktivitas atau mata pencaharian dan juga aspek religi. Dalam aspek bahasa banyak diutarakan melalui percakapan antar tokoh yang menggunakan bahasa jawa. Dalam aspek aktivitas atau mata pencaharian digambarkan bahwa tokoh dalam kehidupan sehari-hari memiliki mata pencaharian sebagai petani dan tukang sapu pada masa penjajahan. Aspek religi tergambar pada nilai-nilai kepercayaan masyarakat jawa yang kental akan hal-hal gaib, seperti pada salah satu cerpen yang berjudul Rawis. Dalam cerpen tersebut Rawis digambarkan sebagai seorang pria yang menjelma sebagai kuda putih. Pria tersebut mendapatkan kekuatan dan dapat menjelma sebagai kuda ia peroleh dari pertapaanya di Gunung Kawi. Pria tersebut bertapa bersama dengan seekor kuda. Ketika bertapa pria dan da tersebut raganya menjadi satu, dan akhirnya pria tersebut memperoleh kekebalan atau kekuatan yang akan ia gunakan untuk membalaskan dendam kematian istri dan anaknya.

\section{DAFTAR PUSTAKA}

Aslan. 2017. Nilai-Nilai Kearifan Lokal dalam Budaya Pantang Larang Suku Melayu Sambas. Ilmu Usbuluddin, Vol. 16 (1) : 11-20.

Dila, Ria Fara dan Sudrajat, Arief. 2017. Ritual Keleman dan Metik Bagi Petani Desa Wonokasian, Kecamatan Bonoayu, Sidoarjo. Paradigma, Vol. 05 (3):1-9.

Gazali, Muhammad Iqbal A. 2010. Keutamaan Membaca dan Menghafal AlQuran . Islam House: 1-8.

Irmawati, Waryunah. 2013. Makna Simbolik

Upacara Siraman Pengantin Adat Jawa.Walisongo, Vol. 21 (2): 309-330.

Manijo. 2016. Dinamika SedulurSikep Kaliyoso: Geneologi Gerakan dan Diskursus Pendidikan Agama. Edukasi, Vol. 11 (1): 51-68.

Mujahidin, Akhmad. 2016. Peranan Kearifan Lokal (Local Wisdom) dalam Pengembangan Ekonomi dan Perbankan Syariah. Ilmiah Syai'ah, vol.15 (2): 153 168. 
Ratna, Nyoman Kutha. 2011. Antropologi Sastra. Yogyakarta: Pustaka Pelajar.

Ratna, Nyoman Kutha. 2013.Penelitian Sastra. Yogyakarta: Pustaka Pelajar.

Setyorini, Nurul dan Rikiana, Suci. 2017. Kajian Arkepital dan Nilai Kearifan Lokal Legenda Di Kota Purworejo Serta Relevansinya Sebagai Bahan Ajar Mata Kuliah Kajian Prosa. Literasi, Vol. 7 (2): 194-102.

Rosyid, Moh. 2014. Urgensi Penelitian Bahasa di Tengah Punahnya Bahasa Lokal. arabia, Vol. 6 (2): 177-200.

Santoso, Imam. 2006. Eksistensi Kearifan Lokal Pada Petani Tepian Hutan dalam Memelihara Kelestarian Ekosistem Sumber Daya Hutan. Wawasan, Vol. 11 (3): 10-20.

Satu, Vincentius.2009. Panduan Belajar dan Evaluasi Sosiologi.Jakarta: PT Gramedia Widiasarana.

Subiyanto, Agus. 2010. Proses Fonologis Bahasa Jawa:Kajian Teori Optimalis. Bahasa dan Seni, (2):154-165.

Wildan. 2013. Kearifan Lokal dalam Novel Seulusoh Karya D. Kemalawati. Bahasa dan Seni, (1):30-39

Yunus, Rasid. 2014. Nilai-Nilai Kearifan Lokal (Local Genius) Sebagai Penguat Karakter Bangsa. Yogyakarta: Deepublish. 